\title{
Síkvidéki mikroerózió szikes talajon Ágota-pusztán (Hortobágyi Nemzeti Park)
}

\author{
TÓTH CSABA \\ Debreceni Egyetem Természeti Földrajzi Tanszék, Debrecen
}

A Hortobágy geomorfológiai szempontból rendkívül változatos, mozaikos mikrodomborzattal rendelkezik. Ez a gazdag formakincs a szikes talajjal borított területeken zajló szikeróziós folyamat következtében alakult ki és formálódik napjainkban is.

1997 őszén, a Hortobágyi Nemzeti Park (HNP) déli pusztáján, Ágota-pusztán (1. ábra) elkezdett részletes terepi méréseken alapuló geomorfológiai kutatásaim célja az volt, hogy a nemzeti park legkülső, az emberi tevékenység által leginkább bolygatott puffer zónájában és az emberi hatásoktól mentes belső területein vizsgáljam a szikpadkás térszínek fejlődését és azok kialakításáert felelős környezeti tényezőket. A vizsgálatokhoz négy mintaterületet választottam ki. Az első két területen antropogén bolygatás nyomait lehet felfedezni, míg a másik két terület emberi zavarástól mentesen fejlődik.

\section{A szikes geomorfológiai kutatások előzményei}

A szikes területek legjellemzőbb formái a szikpadkák, melyek a zárt szikes pusztai gyepekkel (Achilleo-Festucetum pseudovinae, Artemisio-Festucetum pseudovinae) borított, ép talajszelvényü térszínnek (padkatetö), egy általában 5$30 \mathrm{~cm}$ magas, különböző lejtőszögü peremmel (padkaperem) való leszakadása egy alacsonyabb, elvékonyodó „A” szintü térszínbe (sziklanka), majd a legmélyebb szikfokba.

A vonatkozó szakirodalmat áttanulmányozva megállapítható, hogy a szikpadkák kialakulásáról az egyes kutatók nem egyformán vélekednek.

A hazai szikes szakirodalomban elsőként Treitz Péter foglalkozott ezzel a kérdéskörrel, aki a szikpadkák kialakulását a felszín térfogatcsökkenéssel járó összeülepedésével, azaz a csapadékvíznek a kolloidos humusz, kolloidos agyag és a sók feloldásával, valamint a repedések mentén való elszállításával magyarázta (TREITZ, 1924).

* A Magyar Talajtani Társaság és a Magyarhoni Földtani Társulat Mérnökgeológiai Szakosztálya 2000. február 9-én, a szikesedés témakörében rendezett előadóülésén elhangzott előadás anyaga 


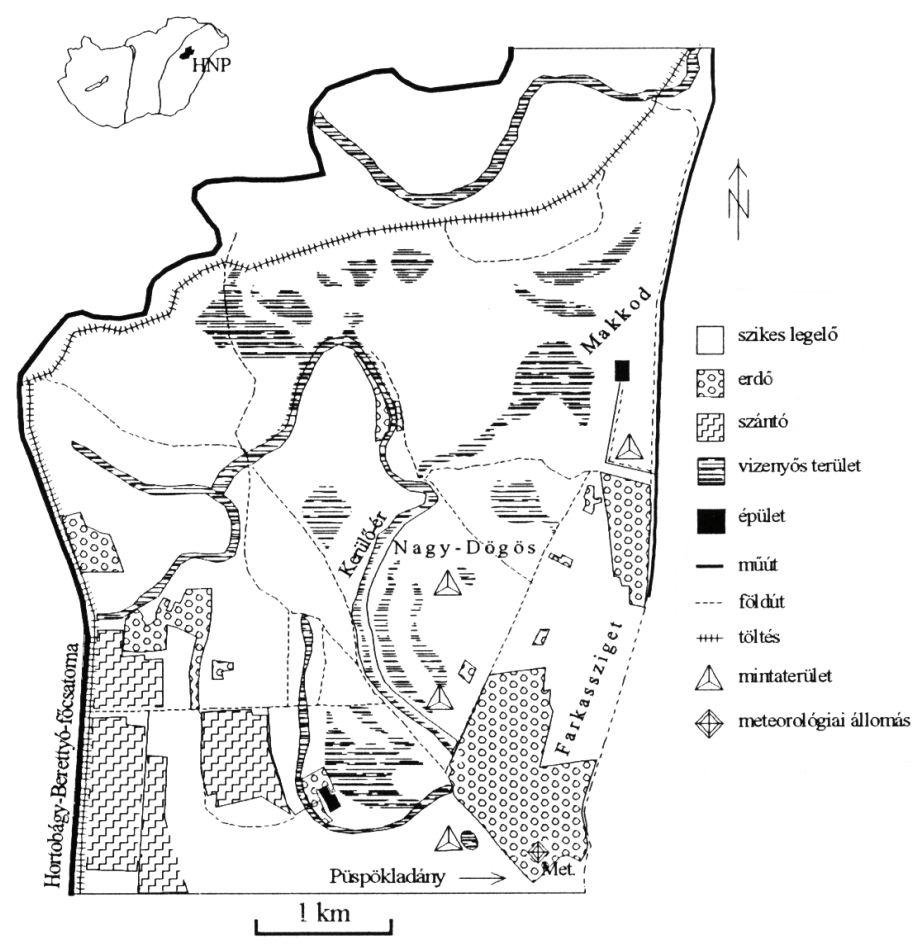

1. ábra

A vizsgált terület térképvázlata (Hortobágyi Nemzeti Park - Ágota-puszta)

A geográfusok közül elsőként Strömpl Gábor neve említendő meg, aki a sziki formák kialakulását szintén az oldással, vagy ahogy ő írta, a marással magyarázta. STRÖMPL (1931) szerint az oldott anyag elszállításának már alárendeltebb szerepe van a formafejlödésben.

Ugyanakkor MAGYAR (1928) az oldás mellett a talajrepedésekben mozgó csapadékvíz mechanikai munkáját és az állati taposás („birkák hegyes körme”) eróziót megindító hatását is kiemelte.

ARANY (1956) a padkásodást már síkvidéki talajeróziónak tekinti. Abban az esetben, ha a szikes talaj nem lúgozódhat ki, akkor a növényzettel nem fedett felszíneken, főképp a repedések mentén, elmosás történik. Tehát a felületi vizek megtámadják a felszínt és az ún. „eróziót szenved”.

A formák kialakulásában fontos szerepet játszik az ,alföldi” lösz, mint talajképző kőzet, amelynek jelentős mennyiségü, finom eloszlású mésztartalma vízzel $\mathrm{Ca}(\mathrm{OH})_{2}$-ra bomlik. A kalcium-hidroxid okozta lúgos $\mathrm{pH}$ kedvez a talajszilikátok feltáródásának, melynek eredményeként agyagásványok (illit, montmorillonit), amorf kovasav és sók keletkeznek. Mivel a kilúgzás következtében 
a talajszelvény mélyebb részeibe mosódik a kolloidos agyag és humusz nagy része, így a felszín 5-15 cm-es fakószürke színü rétegét a csapadékvíz könnyedén megbonthatja (SZÉKYNÉ \& SZEPESI, 1959).

STEFANOVITS (1981) szerint szintén az erózió hatására alakulnak ki a néhány deciméter mély, meredek falú mélyedések. Kialakulásának megindítói sok esetben a zárt növénytakarónak csordajárás vagy dűloúút által megszaggatott foltjai.

A szikes formák keletkezése végeredményben komplex folyamatnak tekinthető, hiszen a lejtés irányában mozgó csapadékvíz mechanikai hatása mellett, huzamosabb talajátázás esetén a víz oldó hatásával is rombolhatja a felszínt. A szolonyec talaj „A”-szintjének lepusztulásával a kedvezőtlen adottságú „B”szint kerül a felszínre, így a sók is a felszín közelébe jutnak (ARANY, 1956; DÖVÉNYI et al., 1977; SZABOLCS, 1954, 1961; 'SigMOND, 1934; TóTH, 1972; VÁRALLYAY, 1967; TÓTH, 1981).

A szikformák nagy része természetes képződményekhez kötődik, például folyóhátak lankásan ereszkedő oldalaihoz, ahol a reliefkülönbség elegendő a csapadékvíz lefolyásához, eróziójához. Ahol azonban az emberi gazdasági tevékenység számos jelével találkozunk (pl. közlekedés - traktornyom, dülőutak; árkok, csatornák, anyagnyerő gödrök), szintén megfigyelhető ezeknek a formáknak a gyors kialakulása.

\section{A vizsgálati módszerek leírása}

A kiválasztott négy mintaterületet az eróziómérések megkezdése elött lézerteodolittal 25 x $25 \mathrm{~cm}$-es hálóban beszinteztük, majd Winsurfer szoftver felhasználásával szintvonalas térképet készítettünk.

A felszín változásainak méréséhez egy profilométer nevü eszközt használtunk (SIRVENT et al., 1997), amelynek segítségével mm-es pontossággal lehet a térszín változásait követni. Ez az eszköz 1,1 x 0,8 m nagyságú fakeret, amelynek vázában $64 \mathrm{db}$ alumínium pálca van elhelyezve. A pálcák talajfelszínre való lehullásuk után kirajzolják a szikpadkák alakrajzát, így a háttérben lévő mm papír segítségével pontosan leolvasható a felszín pusztulása vagy esetleges töltődése (2. ábra). 1998 folyamán negyedévenként, míg 1999-ben havonta végeztem erózióméréseket. A vizsgálatokhoz szükséges meteorológiai adatokat (csapadékmennyiség, csapadékintenzitás) a mintaterületek szomszédságában található ERTI püspökladányi telepének meteorológiai állomásától szereztem be. A talajszelvény vizsgálatához szükséges talajmintákat $2 \mathrm{~m}$ mélységig $10 \mathrm{~cm}$-enként vettük meg Boro típusú talajfúróval. Az alapvizsgálatokat a vonatkozó szabványok alapján a Debreceni Egyetem Természeti Földrajzi Tanszék laboratóriumában végeztük el. A talajtípusok beazonosításához felhasználtam a 25 000-es méretarányú Kreybig-féle geológiai és talajismereti térképlapokat és a hozzájuk tarozó püspökladányi magyarázót (BUDAY \& SCHMIDT, 1938). 


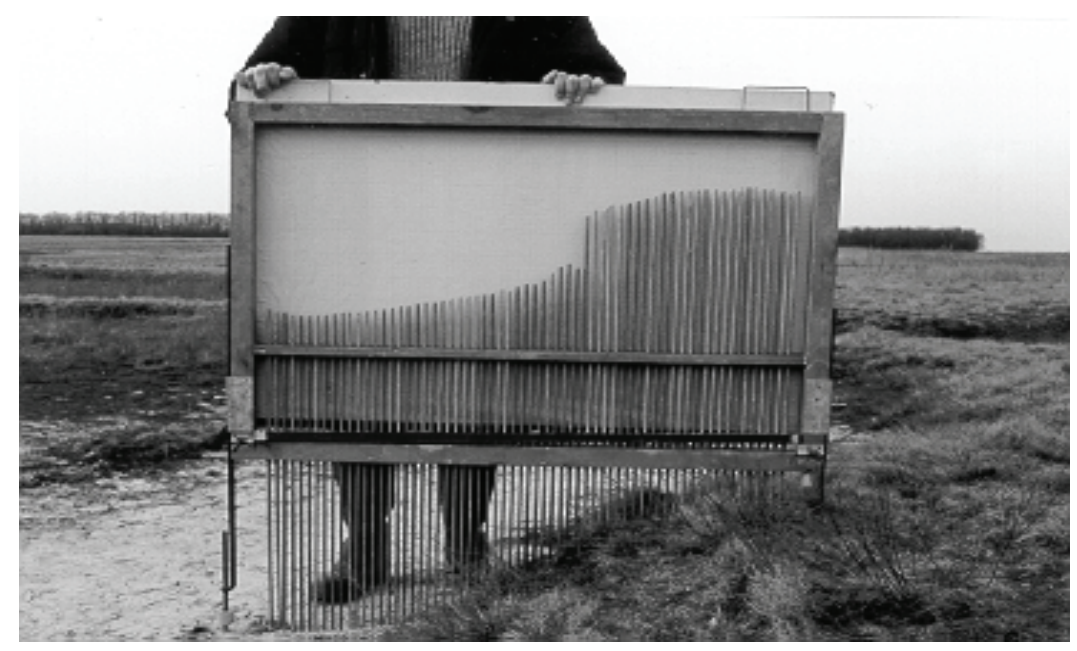

2. ábra

A profilométer mérőeszköz (Nagy-Dögös)

\section{A vizsgált területek geomorfológiai, talajtani és növénytani jellemzése}

1. A makkodi mintaterület egy csapadékvíz-elvezető árok mentén fekszik. Ezt az árkot egy juhhodályhoz vezető betonút mellett mélyítették ki a '70-es évek elején. Ennek következtében a területen - hortobágyi viszonylatban - nagy reliefkülönbség alakult ki: $10 \mathrm{~m}$-en belül $1 \mathrm{~m}$-t csökken a térszín magassága, ami döntően hozzájárul a talajfelszín gyors eróziójához. A talajtani elemzések azt mutatják, hogy vastag humuszos rétegü, magas sótartalmú sztyeppesedő réti szolonyec talajon alakult ki ez az eróziós terület. Az intenzív erózió következtében egy közel $40 \mathrm{~cm}$ magas padkaperem jött létre a csatorna partján, amely fokozatosan hátrál a legelőterület rovására. Emellett képződött egy felső, kisebb magasságú $(7 \mathrm{~cm})$ padkaperem is, melynek előterében több szikerecske munkavégzését lehet tanulmányozni a nedvesebb időszakokban. Ezek az erecskék a heves nyári záporok hatására kipreparáltak több cseréptöredéket, valamint csontdarabot. A régészek elmondása szerint vaskori (szkíta vagy kelta) népcsoportoktól származnak ezek a leletek. Ez a tény is bizonyítja, hogy többszörösen bolygatott térszínnel van dolgunk. A padkatetők felszínén sok, szabálytalan alakú repedés és juh patanyom figyelhető meg, melyek az erózió kiindulásának színhelyei.

A terület legmagasabb részeit zárt Achilleo-Festucetum pseudovinae gyep borítja. A padkatetőkön megindult a talajszelvény leromlása (kolloidális részek kimosódása. areális erózió, juh patákkal való erős felszabdaltság), amit a nö- 
vényzeti kép változása jól tükröz: Puccinelliás gyeppé alakult át az egykori cickafarkas sziki gyep. A padkaelőtereken széles növényzet nélküli sávok (vakszik) alakultak ki, melyek fokozatosan gyér borításértékủ szikfok növényzetbe (Puccinellia limosa) mennek át. Az erózióméréseket két észak-déli, illetve hét nyugat-keleti szelvény mentén végeztem (3. ábra).

1. sz. mintaterület - Makkod

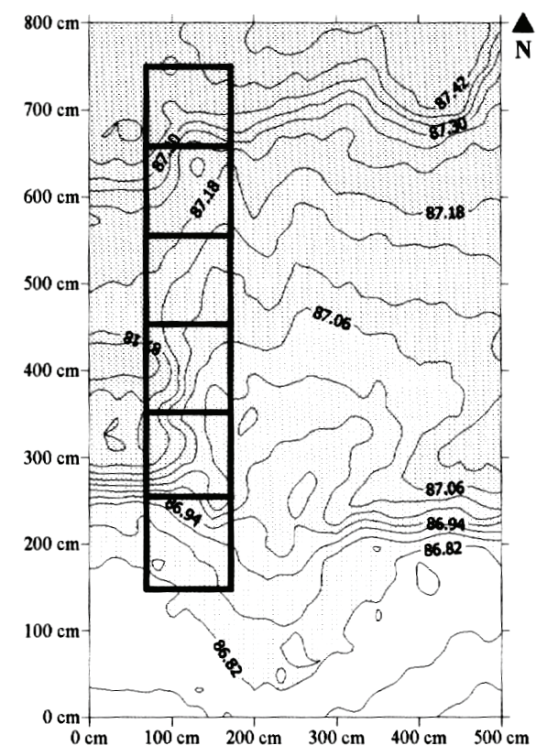

3. sz. mintaterület - Nagy-Dögös

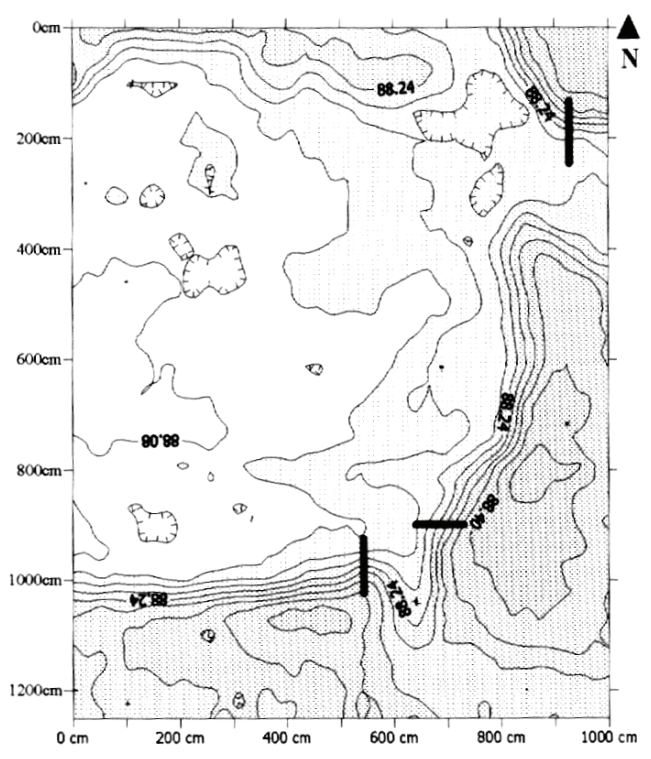

3. ábra

Antropogén és természetes úton kialakult szikpadkás területek térképvázlatai — az eróziómérés szelvényei

2. A farkasszigeti erdőtől nyugatra fekvő szikpadkás mintaterület szintén emberi hatásra alakult ki, hiszen itt egy anyagnyerő gödör kiásása indította el az eróziós folyamatot. Ezt a gödröt 1970-ben mélyítettek ki azzal a céllal, hogy a kitermelt anyagból épített töltéssel megfékezzék a medréből kilépő tiszai árhullámot. Ezzel a beavatkozással szintén jelentős reliefkülönbség jött létre: $18 \mathrm{~m}$ en belül 1,3 m-t lejt a térszín. A gödör közvetlen környezetében, a vékonyabb humuszos rétegü, közepes réti szolonyec talajú terület átlag $18 \mathrm{~cm}$-es padkákkal fokozatosan hátrál. A hátrálás következtében a térszín fel-felszakadozik kisebbnagyobb maradványfelszínekre. Egy ilyen gödörperemi, félszigetszerü szikpadka északi, keleti és déli oldalán végeztem eróziós méréseket. A padkatetőkön található Achilleo-Festucetum pseudovinae gyep leromlott állományai még ellenállnak az eróziónak és az intenzív állati tiprásnak. A szikfok növényzetét Puccinellia limosa és Camphorosma annua egyedek alkotják viszonylag magas borításértékkel. 
3. Nagy-Dögös északi részén, a Kerülö-ér egyik elhagyott medre mentén húzódó folyóhát nyugati oldalán választottam ki harmadik mintaterületemet (3. ábra). Itt tehát már nem az emberi beavatkozás hozta létre a térszínkülönbséget. Ezen a területen csekélyebb (50 m-es távolságon belül $102 \mathrm{~cm})$ reliefkülönbség mérhető a folyóhát tetőszintje és a mocsár legmélyebb pontja között. A folyóhát mocsárra néző, lankásan lejtő oldala jelentősen felszabdalódott a hátráló erózió következtében. A mély réti szolonyec talajú felszín átlagosan 25-30 cm magas padkaperemmel hátrál a sziki legelő rovására. A mintaterület padkatetőit zárt Artemisio Festucetum pseudovinae gyep borítja. A kopár padkaperemeken néhol egy-egy Artemisia santonicum egyed fordul elö. A padkaelőtér szikfok növényzetét szintén a Puccinellia limosa és a Camphorosma annua egyedek képviselik.

4. Nagy-Dögös déli részén, az előző mintaterülettel szomszédos mocsár nyugati oldalán választottam ki negyedik mintaterületemet. A négy terület közül a reliefviszonyok itt kedveznek legkevésbé az eróziónak, hiszen $50 \mathrm{~m}$-en belül (mocsáralj és a legmagasabb mocsárpart között) csak $57 \mathrm{~cm}$-t lejt a terület. A mély réti szolonyec talajú, zárt Artemisio Festucetum pseudovinae gyeptakaróval borított terület három, a mocsár felé közeledve egyre magasabb $(8-19 \mathrm{~cm})$ peremmel „szakad le” az erózióbázis irányába. A lankás padkaperemek felszínét zárt ürmös szikes gyep takarja, ami a padkaelötéren hirtelen átmegy egy camphorosmás szikfok társulásba.

\section{A vizsgálati eredmények}

A szikes talajok eróziójának fontos tényezője a csapadék mennyisége és föképpen annak intenzitása. A profilométer által kapott eróziós értékeket ezért a vizsgált időszak csapadékadataival érdemes összevetni. Az adatokból kitünik, hogy a nyári időszak nagy mennyiségü (60-120mm/hó) és nagy intenzitású (6$8,3 \mathrm{~mm} / 30 \mathrm{~min}$ ) csapadékai közel kétszer akkora pusztulást idéznek elö, mint a csendes őszi vagy kora tavaszi esők. A fagyos, hótakaróval borított felszín nyugalomban van, de a tavaszi hóolvadás a kis intenzitású (1-2 $\mathrm{mm} / 30 \mathrm{~min})$ esőkhöz hasonló változásokat eredményezhet (4. ábra). Ezek a megállapítások csak az intenzíven formálódó makkodi és farkasszigeti mintaterületre érvényesek. A zárt növénytársulásokkal fedett nagy-dögösi területeken ez a folyamat nem enynyire egyértelmú.

\section{A makkodi mintaterület erózióméréseinek eredményei}

A mérések eredményeként a területet 6 zónára lehet felosztani (5. ábra):

Felső padkatetö - A legmagasabb térszín, ahol a növénycsomókkal borított szolonyec talaj minden rétege megtalálható, azonban felszíne gyorsan erodálódik. Két év leforgása alatt átlagosan 3-6 cm-rel lett alacsonyabb, emellett két, 


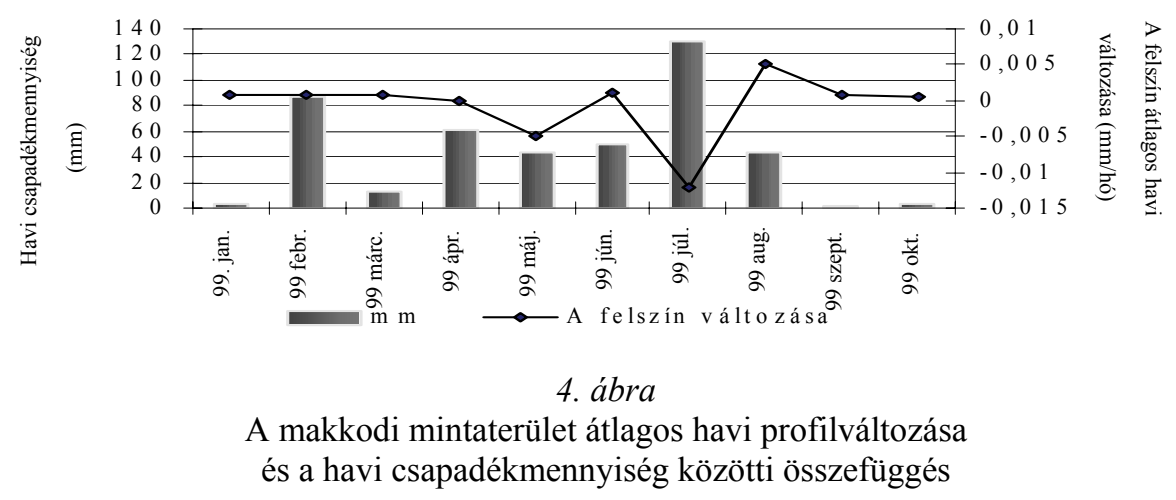

gyorsan mélyülő (8-19 cm/2 év) és táguló lyuk képződött rajta, amelyek juh patanyomokból alakultak ki. Ezek a lyukak és repedések levezetik a felszíni vizeket a talaj mélyebb rétegeibe, és azok a padkaelőtéren mint „búvópatakok” törnek a felszínre. Feltehetőleg ez a felszín alatti anyagkimosódás szerepet játszik a padkatető 2 év alatti megsüppedésében. Emellett a felszínen az areális erózió nyomait is fel lehet fedezni. A talaj „A”-szintjének vékonyodásával, jelentkezik a Festucetum gyep fellazulása, fajösszetételének megváltozása, amit a Puccinellia fajok egyedszám növekedése jelez. Ez a folyamat jól mutatja a talaj kolloidális alkotórészeinek a csapadékvízzel a „B”-szintbe, ill. a padkaelőtérre történő lemosódását. A padkatető pusztulását tovább erősíti az intenzív legeltetés (állati tiprás), amelynek következtében a növénytakaró fellazul, így csak 20$40 \%$-os a növényzeti fedettség. Bizonyos időszakokban (ősszel és tavasszal) kismértékü magasodás is megfigyelhetö, ami feltehetőleg a magasabb térszínek felől érkező anyag akkumulációjával magyarázható.

Felsö padkaperem - A növényzettel nem borított perem magassága $7,5 \mathrm{~cm}$, lejtőszöge $45^{\circ}$. A perem 1998-ban 5,5 cm-t, 1999-ben 15,1 cm-t hátrált a legelöterület irányába.

Felső padkaelötér vagy sziklanka - Ez az areális és a lineáris erózió fő színtere. A terület két év leforgása alatt átlagosan 5-6 cm-t alacsonyodott. A tavaszi lassú hóolvadás ill. a csendes őszi esők nem okoznak nagy eróziót, sőt néhány mm-es akkumulációt is meg lehet figyelni a szikerek „medrében” és partjukon. Ekkor ugyanis a vizek nem képesek elszállítani hordalékukat az erózióbázisig. A nagy intenzitású nyári záporok vize azonban már erodál mind areálisan, mind az erek mentén lineárisan. Havonta akár $2 \mathrm{~cm}-\mathrm{t}$ is mélyülhetnek ezek az erek. Mivel itt a talajszelvény „lefejezett”, azaz a legkedvezőtlenebb adottságú „B”szint kerül a felszínre, és az anyagmozgás ebben a zónában a legintenzívebb, a növényzet csaknem teljesen hiányzik. A természetes körülmények között kialakult sziklankák növénytársulásaiból itt csak a Puccinellia limosa jelenik meg a szikerek peremén néhány szál formájában. 


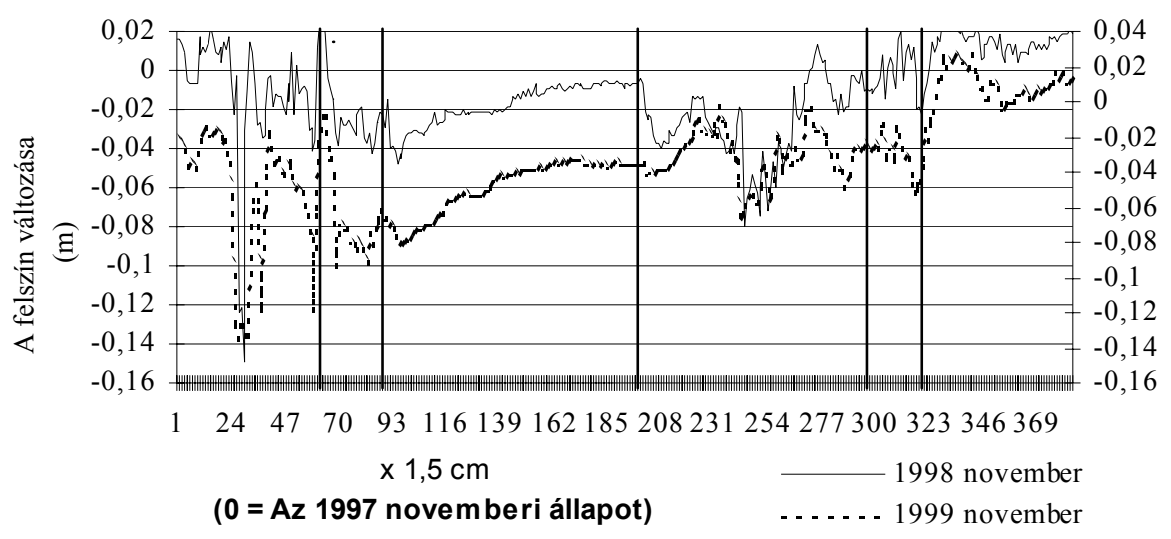

5. ábra

A makkodi mintaterület profiljának változása két év alatt

Alsó padkatető - A felszín alakulása hasonló a felső padkatetőhöz. Itt is 3-6 cm-es átlagos alacsonyodással kell számolni. A peremi területek pusztulása a legszembetűnőbb, míg a növénytakaróval borított központi része kevésbé pusztul. A patanyomok kimélyülése szintén megindult, föképpen 1999 nyarán zajlott le jelentős erózió. A felső sziklankán lefutó szikerecskék néhol az alsó padkatetöt is áttörik, és ezáltal a tetöt szigetekre szaggatják szét. Ez történt az eróziómérés szomszédságában is. Az erózióból kimaradt szigeteken a zárt sziki gyep fajait (Artemisia santonicum, Podospermum canum, Festuca limosa) még megtalálhatjuk, közéjük azonban az elvékonyodó „A”-szint miatt már a Puccinellia limosa is betelepült.

Alsó padkaperem - Magasabb $(24 \mathrm{~cm})$ és meredekebb $\left(72^{\circ}\right)$, mint a felső leszakadás. 1998 folyamán 2,75 cm-tt, 1999-ben 5,5 cm-t hátrált a perem. Feltehetőleg méretéből és meredekségéből kifolyólag az állati tiprás ezen a helyen kisebb mértékü vagy hiányzik, így lassúbb hátrálása érthető.

Alsó padkaelötér - „hordalékkúp” - A két szikerecske itt rakja le hordalékát, amiből egy szabályos legyező alakú hordalékkúp épül. A legelső méréshez képest felszíne fokozatosan $3 \mathrm{~cm}$-t emelkedett. Heves esőzések alkalmával azonban előfordult, hogy anyaga az erózióbázis felé (árok) átmosódik, így ekkor átmenetileg alacsonyabbá válhat néhány mm-rel. Ezen a területen a fenti szakaszokkal ellentétben nem a folyamatos pusztulás, hanem az állandó akkumuláció szab határt a fejlettebb növényközösségek kialakulásának. A növénytakaró záródása itt is csak 20-40 \%-os. A csapadékvízzel és a lemosódó talajjal ideérkező növényi magvak miatt azonban fajgazdagabb vegetáció alakult ki, mint a fenti erősen erodálódó területeken. 
A padkatetőtől az árok aljáig mélyített négy talajfúrással tisztázni lehetett a terület rétegtani jellemzőit (6. ábra). A terület intenzív eróziójára utal, hogy a '70-es évek elején kiásott, közel $3 \mathrm{~m}$ mély árokba 30 év leforgása alatt $180 \mathrm{~cm}$ vastag lepusztulási anyag rakódott le. Ez az anyag kezdetben egy szürkésbarna színű, magas humusztartalmú üledék, amely nem más, mint az árok peremén fekvő szolonyec térszín „A”-szintjének lepusztulási anyaga. Később a „,B”-szint felszínén történő kovasav-felhalmozódás jelentette a fö lepusztulási anyagot, ami természetesen keveredik a felső szintek felől érkező némi humuszos lepusztulás termékkel.

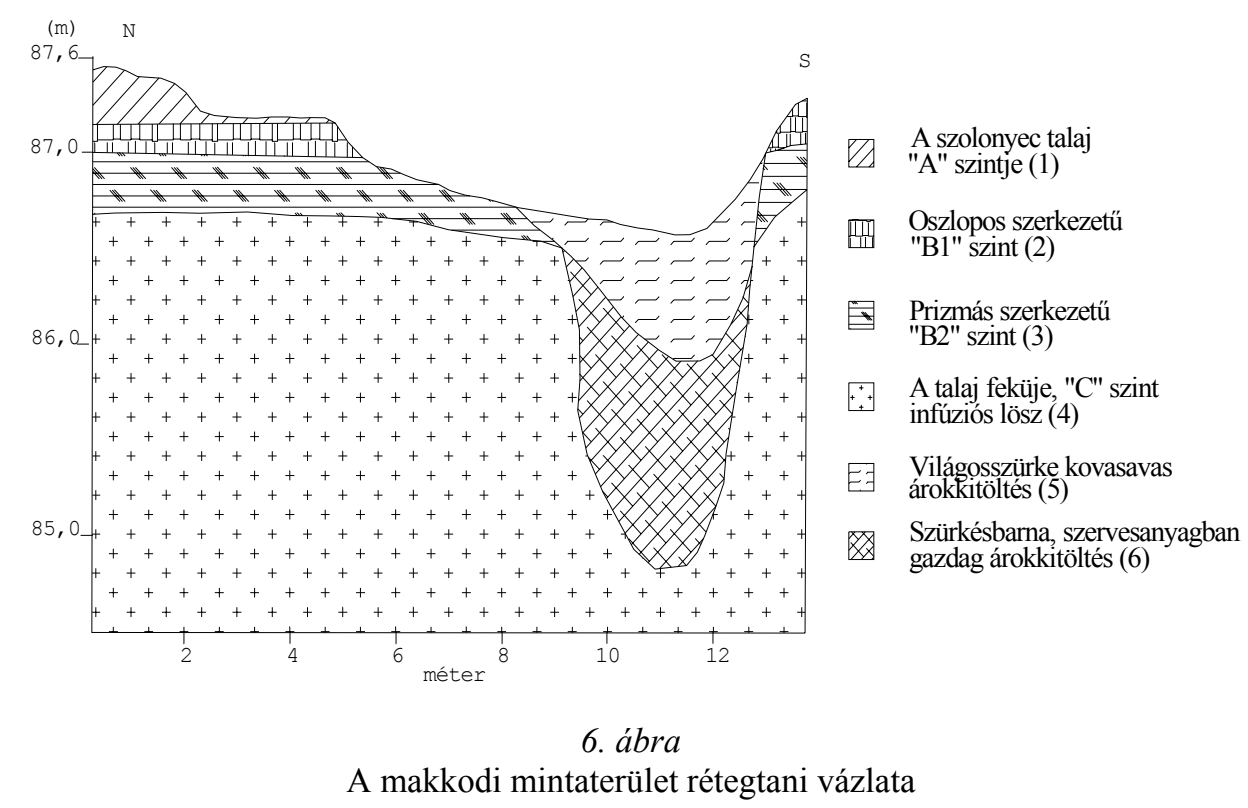

\section{A farkasszigeti mintaterület eróziómérésének eredményei}

Mivel ezen a területen egy pontból kiindulva három égtáji irányban (észak, kelet és dél) végeztem méréseket, a padkatető mindhárom esetben azonos.

A padkatetőt közel $90 \%$-os zártságú Festucetum gyep borítja. A padkatető felszínén a hóolvadás és a kis intenzitású tavaszi esőzések időszakában átlagosan $1 \mathrm{~cm}$-es magasodást mértem, ami csakis a növényzet burjánzásából származhat, mivel ez a legmagasabb térszín, így anyagutánpótlást nem kaphat. A heves nyári záporok időszakában, azonban ugyanilyen mértékben, de már csökken a padkatető magassága, ami a fücsomókkal nem védett felszín areális lepusztulását jelenti. A felszín még viszonylag jól ellenáll az állati taposásnak, kimélyülő lyukakat itt nem találtam. 
Általánosságban elmondható, hogy a gödör mentén a padkaperemek magasabbak $(19-22 \mathrm{~cm})$ és meredekebbek $\left(65-80^{\circ}\right)$, mint a gödörrel ellentétes irányba nézők $\left(13 \mathrm{~cm}, 47^{\circ}\right)$. A perem átlagosan $5,2 \mathrm{~cm}$-t hátrált két év leforgása alatt, a mélyedés irányába néző északi és keleti peremek esetében (1. táblázat). A peremek hátrálásához a juhok nagymértékben hozzájárultak, erről tanúskodnak a patanyomok. A növényzettel fedett déli padkaperemen hátrálást nem lehetett kimutatni.

1. táblázat

A mintaterületeken bekövetkezett felszínváltozások 1997. november 5. és 1999. november 7. között

\begin{tabular}{|c|c|c|c|c|c|c|}
\hline \multirow{3}{*}{$\begin{array}{l}\text { Minta- } \\
\text { területek }\end{array}$} & \multirow{3}{*}{$\begin{array}{c}\text { Padka- } \\
\text { tetö, } \\
\text { cm }\end{array}$} & \multicolumn{4}{|c|}{ Padkaperem } & \multirow{3}{*}{$\begin{array}{c}\text { Padka- } \\
\text { előtér, } \\
\text { cm }\end{array}$} \\
\hline & & \multirow{2}{*}{$\begin{array}{c}\text { Lejtö- } \\
\text { szög, } \\
\text { o }\end{array}$} & \multirow{2}{*}{$\begin{array}{l}\text { Relatív } \\
\text { magas- } \\
\text { ság, cm }\end{array}$} & \multicolumn{2}{|c|}{ Hátrálás, cm } & \\
\hline & & & & 1998 & 1999 & \\
\hline Nagy-Dögös & & & & & & \\
\hline déli terület & \pm 1 & 18 & 8-19 & 0 & 0 & $0-0,5$ \\
\hline északi terület & $0--1$ & 75 & $28-29$ & 2,1 & 2,1 & $1-2$ \\
\hline Farkassziget & -1 & 65 & $13-22$ & 2,3 & 2,9 & $1-1,5$ \\
\hline Makkod - & & & & & & \\
\hline $\begin{array}{l}\text { alsó padka } \\
\text { felsó padka }\end{array}$ & $\begin{array}{l}-3--6 \\
-3--6\end{array}$ & $\begin{array}{l}72 \\
45\end{array}$ & $\begin{array}{c}24-38 \\
7,5\end{array}$ & $\begin{array}{l}2,7 \\
5,5\end{array}$ & $\begin{array}{c}5,5 \\
15,1\end{array}$ & $\begin{array}{c}3 \\
-5--6\end{array}$ \\
\hline
\end{tabular}

A padkaperemek $20 \mathrm{~cm}$-es előterében átlagosan 1-1,5 cm-es akkumulációt lehetett mérni, míg a sziklankák távolabbi pontjain, föképpen a gödör peremén, $1,5-2,5 \mathrm{~cm}$-es pusztulást regisztráltam.

\section{A nagy-dögösi mintaterületek eróziómérésének eredményei}

Mind az északi, mind a déli mintaterületre jellemző, hogy természetes körülmények között alakultak ki, az ember kizárólag legeltetéssel befolyásolta azok fejlődését. Ez a beavatkozás 1997 őszéig tartott Ekkor ugyanis felhagytak a szarvasmarhatartással az északi területen. A két terület között kizárólag a szikpadkák méretében van különbség, ami a reliefkülönbségekre vezethető vissza.

Mind a két terület padkatetőire jellemző, hogy két év leforgása alatt rajtuk változást alig lehet kimutatni. A fǘcsomókkal, moha- és zuzmótakaróval kevésbé védett tetőrészleteken 1-1,5 cm-es mélyedések alakulhatnak ki az intenzív csapadékos nyári időszakokban. Azonban több helyen a dús vegetáció miatt ugyanilyen mértékü „,magasodást” mértem.

A padkaperemek esetében a két területen jelentősebb különbségek vannak. Az északi terület magasabb $(29 \mathrm{~cm})$ és meredekebb $\left(75^{\circ}\right)$ peremekkel jellemezhetö, míg a déli területen csak max. $19 \mathrm{~cm}$ magas és $18^{\circ}$-os lejtöszögü pe- 
remek fordulnak elő. Az északi terület padkaperemeinek tetején $0,5 \mathrm{~cm}$, míg az alsó részen $2,1 \mathrm{~cm}$ hátrálás volt tapasztalható két év leforgása alatt, ami a peremek meredekebbé válását jelenti. A déli terület zárt ürmös sziki gyeppel borított padkaperemein hátrálásról nem beszélhetünk.

Mind a két terület padkaelőtereire jellemző egy 20 cm-es akkumulációs zóna megléte, ahol évente, a padka jellegétől és az oldalról betorkolló szikerecskék hordalékszállításától függően $0,5-2 \mathrm{~cm}$ anyag halmozódik fel (1. táblázat). A távolabbi területeken ismét az erózió (lineáris vagy areális) uralkodik.

\section{Összefoglalás}

A szikpadkák két éves eróziómérési adatsorából az alábbi megállapításokat lehet levonni. Ágota-puszta gazdag mikrogeomorfológiai adottságait több tényező együttes hatásának köszönheti. Elsődleges fontosságú tényező a szikes talajok jelenléte, amely megteremti a padkásodás lehetőségét, de nem határozza meg annak mértékét, ütemét. A külső tényezők közül a reliefviszonyok döntőek lehetnek a formák alakulása szempontjából. Nagyobb magasságkülönbséggel rendelkező területeken ugyanis a formák markánsabbak és gyorsabban fejlődnek, mint a viszonylag kis felszíni eséssel jellemezhető területeken. A reliefenergia mellett a csapadékmennyiség és a csapadékintenzitás nagyon fontos tényezö. A téli és kora tavaszi hónapok hótakarója, valamint kisebb mennyiségü és intenzitású esők nagyságrendekkel kisebb mértékủ eróziót indítanak el, mint a nyári hónapok heves, nagy intenzitású záporai.

A természetes tényezők mellett az intenzív legeltetés okozta állati taposás (juh, szarvasmarha) és az egyéb emberi beavatkozások - föképpen a negatív formák létrehozása (árkok, gödrök, közlekedés - traktornyom, dülőutak) - egyenrangú formaképző tényezők az előbb említettekkel.

Ha egy területen a felsorolt hatótényezők mindegyike koncentrálódik, akkor alföldi viszonylatban is gyors, intenzív erózióval kell számolni (Makkod). Ellenben, ha bizonyos környezeti faktorok hiányoznak vagy kisebb intenzitásúak, akkor a formák fejlödése lelassul, esetleg stagnálhat (Nagy-Dögös déli területe).

\section{Irodalom}

ARANy S., 1956. A szikes talaj és javítása. Mezögazdasági Kiadó. Budapest. 227-233.

BUDAY GY. \& SCHMIDT E. R., 1938. Magyarázatok Magyarország geológiai és talajismereti térképeihez Püspökladány 5066/4 sz. 1:25 000. 61-64.

DöVÉNYI Z. et al., 1977. Természeti és antropogén folyamatok vizsgálata a kígyósi puszta területén. Természetvédelmi Évkönyv 2. Békéscsaba. 43-66

MAGYAR P., 1928. Adatok a Hortobágy növényszociológiai és geobotanikai viszonyaihoz. Erdészeti Kísérletek. 30. 26-63. 
'SiGMOND E., 1934. Általános talajtan. Szerző kiadása.

SIRVENT, J. et al. 1997. Erosion rates in badland areas recorded by collectors, erosion pins and profilometer techniques (Ebro Basin, NE-Spain). Geomorphology. 18. 61-75.

Stefanovits P., 1981. Talajtan. Mezőgazdasági Kiadó. Budapest.

STRÖMPL G., 1931. A szik geomorfológiája. Földrajzi Közlemények. 4-5. 62-67.

SzABOLCS I., 1954. A Hortobágy talajai. Mezőgazdasági Kiadó. Budapest.

SzABOLCS I., 1961. Vízrendezés és öntözések hatása a tiszántúli talajképződési folyamatokra. Akadémiai Kiadó. Budapest.

SZÉKYNÉ F. V. \& SZEPESI K., 1959. Az „,alföldi” lösz szerepe a szikes talajképződésben. Földtani Közlöny. LXXXIX. kötet (1) 54-63.

TóTH A. 1981. Degradáló löszpusztagyepek reliktum foltjainak synökológiai viszonyai a HNP északi és nyugati pusztáin. Doktori értekezés. Kisújszállás. 55-61.

Tóтн B. et al. (Szerk.), 1972. Szikesek fásítása. Akadémiai Kiadó. Budapest.

TREITZ P., 1924. A sós és szikes talajok természetrajza. Stádium Sajtóvállalat Részvénytársaság. Budapest. 224-263.

VÁRALlYAY GY., 1967. Vitatható megállapítások dr. H. Franz: Adatok a negyedkori rétegeződéshez és a szikes talajok geneziséhez a Hortobágyon és annak peremvidékén c. dolgozatában. Agrokémia és Talajtan. 16. 448-458.

Érkezett: 2001. március 5. 